\title{
The Influences of Good Corporate Governance and Company Age on Integrated Reporting Implementation
}

\author{
Maharanny Yulyan \\ Faculty of Economics and Business \\ Universitas Padjadjaran \\ Winwin Yadiati \\ Faculty of Economics and Business \\ Universitas Padjadjaran \\ Said Aryonindito \\ Faculty of Economics and Business \\ Universitas Padjadjaran
}

\begin{abstract}
This study aims to determine Good Corporate Governance's effect and the firm's age on integrated reporting implementation. The corporate governance structure refers to the board of commissioners, independent commissioners, the audit committee, and the meeting attendance, the study employed company size as a control variable. Several mining companies listed on the Indonesia Stock Exchange (IDX) from 2016 to 2018 were selected through a purposive sampling technique as the population of this study. Based on predetermined criteria, the selected samples of this study were 44 of 132 data. A quantitative method with descriptive statistics was chosen as a research design, and it also gained secondary data from the annual report as a data source. The study results revealed that the board of commissioners, the independent board, and the company's age and size as control variables influence integrated reporting implementation. Otherwise, the audit committee and meeting attendance do not affect the implementation of integrated reporting. Lastly, the board of commissioners, the board of independent commissioners, the audit committee, meeting attendance, company age and size as control variables jointly influenced integrated reporting implementation.
\end{abstract}

Keywords: Company Age, Company Size, Good Corporate Governance structure, Integrated Reporting

\section{Introduction}

A company annually publishes an Annual Report addressing some related parties, including investors, creditors, and governments as a tool in making decisions. As stated by ACCA and Eufoif (2013), up to this time, nonfinancial reports were not sufficiently relevant, so it is highly suggested to integrate financial reports. The International Integrated Reporting Council (IIRC) developed integrated reporting for companies in 2010 and published an integrated reporting framework as a type of company performance reporting that emphasises financial reports' transparency in 2013. IIRC further explains that integrated reporting is a brief communication media describing the organisational strategy, governance, performance, and prospects to create value in the short, medium, and long terms. Integrated Reporting is expected to help management, especially in deciding for all stakeholders and present the bridges between financial and non-financial reports to create corporate value (Kilic \& Kuzey, 2018).

The writing process of annual financial statements for business entities in Indonesia refers to several sources, such as Financial Accounting Standards (SAK), Bapepam LK before 2016, Financial Authority Regulation (OJK) 2016 as the mandatory national standards. It recently has adopted the Global Reporting Initiative (GRI) and the International Integrated Reporting Council (IIRC) as voluntary national standards. However, Integrated Reporting in Indonesia is not yet mandatory, so it is still a voluntary disclosure. The term voluntary disclosure requires the companies to be free in selecting the type of 
information to be disclosed and support decision making. Some countries have required reports, namely the United States of America, United Kingdom, Germany, Brazil, India, Malaysia, Singapore, Japan, Australia, and New Zealand.

Moreover, some companies have improved their financial statements by adding non-financial reporting information. It is crucial for stakeholders because these statements consist of business strategies, risks and opportunities, corporate governance, and prospects. Therefore, to meet the reports' needs, it does not necessarily focus on quantitative reports, but it requires qualitative ones (Needles et al., 2016). Churet et al. (2014) researched IR's application in 2000 companies listed on the S\&P Global Broad Market Index. The study looked at the suitability of the company's annual report against IR during the 2011-2012 period. The results showed a significant increase. In 2012, telecommunication sector companies implementing the IR concept increased 35 per cent, utilities $26 \%$, industrial $16 \%$, energy $15 \%$, and finance $14 \%$ from 2011. Chariri and Januarti (2017) researched Integrated Reporting elements in the Annual Report of Indonesian Companies, which stated that companies listed on the Indonesia Stock Exchange were still relatively low to include Integrated Reporting elements. Kustiani's research (2017) concluded that the readiness of companies in Indonesia in adopting Integrated Reporting is quite good, with an average of $64 \%$ of companies have implemented five elements of Integrated Reporting.

The government's role in directing go public companies has been carried out, and this is in the XVIIth National Accounting Symposium (NA) 2014 with a discussion of "The Role of Accountants in Sustainable Development through Integrated Reporting". With this event, the government expects companies in Indonesia to implement the Integrated Report. Research conducted by Rahayuningsih (2019) states that no regulations are requiring the implementation of integrated reporting in company annual reports so that it is said that integrated reporting is voluntary (voluntary disclosure). It makes researchers want to know what factors can influence a company to implement integrated reporting as the company's annual report.
Azam et al. (2011); Cheng et al. (2014): Serefeim (2015) in (Utami, 2016) that IR has the benefit of increasing transparency in company operations, by increasing transparency it will increase stakeholder trust. The delivery of information in a transparent manner can be encouraged by good corporate governance (GCG). Several studies have examined the relationship between corporate governance mechanisms and market reactions in developed countries, but this has undoubtedly not yielded the same results. For countries that are still developing, corporate governance is an essential measure for a company to run.

Research on IR in Indonesia has not been widely conducted because IR is a relatively new concept. The reason for choosing a mining company is because it is closely related to environmental exploration, which can damage the environment. It can directly or indirectly impact the balance of the environment and the life of the surrounding community. Rudi Kurniawan (2017) states that the audit committee affects reporting with an integrated reporting framework. This study is different from research conducted by Dianar Prawesti (2016), which states that the audit committee does not affect integrated reporting, but company age affects the disclosure of integrated reporting. This study's results are not in line with research conducted by Erna Wati Indriani (2013), which shows that listing age does not affect the extent of voluntary disclosure.

\section{Literature Review}

\section{Agency Theory}

This theory explains how company owners turn over the company to professionals (agents) to run their business. Principals are shareholders or investors who employ agents. The goal is that the company owner can make a profit at a lower cost. The use of agency theory in this study aims to see how the asymmetric relationship between company management and company owners is minimised or managed by implementing good corporate governance. Ideally, by implementing good corporate governance and presenting reporting correctly, company owners will have confidence in company management regardless of their age. By applying these principles, companies can 
reduce the costs of monitoring financial statements.

\section{Legitimacy Theory}

Legitimacy theory focuses on the company's interaction with external parties by considering the prevailing social system. Through this legitimacy theory, the researcher tries to determine whether companies have implemented Good Corporate Governance and reported integrated reporting to get a positive image from the public because they have accounted for its performance. Stakeholder theory focuses on ways that companies can use to manage the company's relationship with its stakeholders. Stakeholder theory implies that a company is not an entity that only operates for its interests, but must provide benefits for its stakeholders such as shareholders, creditors, consumers, suppliers, government, society, analysts, and other parties. Through stakeholder theory in this study, the researcher tries to determine whether the application of integrated reporting as a form of information disclosure can increase trust and strengthen corporate relationships.

\section{Integrated Reporting}

The International Integrated Reporting Council (IIRC) defines integrated reporting as a process that produces brief communications about the company's strategy, governance, performance and prospects in the context of its external environment, which leads to value creation in the short, medium and long term (IIRC, 2013). A financial report prioritises financial information through integrated reporting, but non-financial information is also complementary, which will provide benefits or added value to the company. External reporting, namely financial reporting, management reporting and sustainability reporting, is simplified into one Integrated Reporting. The IR element is based on the company's IR Frame. Outlook includes work prospects that must be met so that a report or challenges that the company will face is referred to as a company report. Integrated as follows:

\section{Good Corporate Governance}

Based on the OECD (Organization for Economic Co-operation and Development), it can be seen that the goal of corporate governance is that companies can fulfil the rights and obligations of parties involved in company activities, such as employees, customers, suppliers, business partners, society/public, legislators. , regulators, and policymakers to create added value for stakeholders. Ideally, a company should be free from conflicts of interest, influence, and pressure from other parties to make neutral and objective decisions. The board of commissioners is the party that supervises management policies, ensures that companies run according to general standards, and provides advice to directors and ensures that the company has implemented GCG.

An independent commissioner consists of members who do not have a business or family relationship with the controlling shareholder, board of directors, and commissioners. Independent commissioners are appointed based on their performance and professionalism towards their interests (all stakeholders' interests). At least a company has $30 \%$ Independent Commissioners from the Board of Commissioners elected through the General Meeting of Shareholders (GMS). According to Hermalin \& Weisbach (1998), a large proportion of Independent Commissioners in the board structure will benefit the company because monitoring the company will be better and broader regarding their perspective and expertise.

Based on the Financial Services Authority Regulation Number 55 / POJK.04 / 2015 concerning the formation and work implementation guidelines of the audit committee, it explains that the audit committee is a committee formed by and responsible to the board of commissioners in helping carry out the duties and functions of the board of commissioners. The audit committee has the task of supervising company activities to prevent fraud. The existence of fraud and negligence committed by directors in the company is a factor in forming the audit committee (Agoes \& Ardana; 2009). The minimum number of audit members in a company consists of three people, where one member is from an independent commissioner, and the other two are from outside the company. 
Company Age

According to Sawitri (2016), companies that have been listed on the Indonesia Stock Exchange for a more extended period have broader and more knowledge about the information needs of investors and companies who have had more experience in preparing company reports for a longer time. The longer the company operates, the more experience the company has in disclosing information needed by stakeholders to improve company reporting to be better and more complete.

\section{Research Methods}

This research uses descriptive statistical research methods. Descriptive statistics are statistical methods used to describe or describe the data that has been collected as is without intending to draw generalised conclusions (Sekaran, 2014). The data analysis method used in this study is the Multiple Regression Analysis. This study's population are mining companies listed on the Indonesia Stock Exchange (BEI) for the period 2016-2018. The sample used is a mining company that has the following criteria:

Table 1. Sample Selection

\begin{tabular}{clcc}
\hline No & Criteria & Total & Accumulation \\
\hline 1 & $\begin{array}{l}\text { Mining companies listed on the Indonesia Stock } \\
\text { Exchange 2016-2018 }\end{array}$ & 50 & 50 \\
\hline 3 & Issuers that experienced delisting in 2016-2018 & 3 & 47 \\
\hline 4 & The annual report not available 2016-2018 & 4 & 44 \\
\hline Research period & & 3 \\
\hline Total Research Sample & & 132 \\
\hline
\end{tabular}

Based on the criteria mentioned above, 50 mining companies are listed on the Indonesia Stock Exchange for the 2016-2018 period. A total of 44 companies that meet the research criteria are eligible to be sampled. The total for three periods was 132 samples.

\section{Result and Discussion}

Descriptive Analysis
The first independent variable is BODSize with the average number of commissioners in mining companies listed on the IDX in 20162018 is four people. With the number of commissioners at most ten people owned by INCO (PT. Vale Indonesia) in 2016- 2017, at least two people were owned by ARTI (PT. Ratu Prabu Energy Tbk) in 2016-2018. From these results, mining sector companies listed on the IDX during 2016-2018 have implemented OJK Regulation No.33 of 2014, which states that the company's minimum number of commissioners is two people.

Table 2. Descriptive Statistics

\begin{tabular}{llllll}
\hline & N & Minimum & Maximum & Mean & Std. Deviation \\
\hline BOCSize (X1.1) & 132 & 2,00 & 10,00 & 4,2500 & 1,67776 \\
\hline BOCInd (X1.2) & 132 & 0,20 & 0,67 & 0,4159 & 0,10268 \\
\hline AUDTC (X1.3) & 132 & 2,00 & 5,00 & 3,0909 & 0,43606 \\
\hline MetATC (X1.4) & 132 & 44,44 & 100,00 & 90,3202 & 12,55706 \\
\hline Umur (X2) & 132 & 1,00 & 28,00 & 13,1136 & 7,25400 \\
\hline Size (K) & 132 & 25,65 & 34,31 & 29,4138 & 1,85017 \\
\hline IR (Y) & 132 & 0,45 & 0,95 & 0,8320 & 0,09159 \\
\hline
\end{tabular}


The BOCInd average of mining companies listed on the IDX in 2016-2018 is 0.4159. It shows that the average number of independent commissioners in a mining company sample is $41 \%$ of the commissioners' total board. The highest BOCInd reaching 0.67, which is $60 \%$ of the total number of commissioners, one of which is owned by APEX (PT. Apeindo Pratama Duta Tbk) in 2016 and the lowest BOCInd reaches 0.20 which is owned by MITI (PT. Mitra Investindo Tbk) in 2016, where the composition of independent commissioners was only $20 \%$ of the total board of commissioners. Based on the OJK Regulation concerning the Issuer's Board of Directors and Board of Commissioners, it is stated that if the board of commissioners is more than two people, the number of independent commissioners must be at least $30 \%$ of the total number of commissioners. Judging from MITI's composition only $20 \%$ of the total board of commissioners, MITI (PT. Mitra Investindo Tbk) in 2016 did not comply with existing regulations.

The average number of audit committees at mining companies listed on the IDX in 2016-2018 is three people. With the number of audit committees at most five people owned by ANTM (PT. Aneka Tambang Tbk) in 2017, at least two people were owned by BIPI (PT. Astrindo Nusantara Infrastruktur Tbk) in 2016. The average attendance of board of commissioners meetings at mining companies listed on the IDX in 2016-2018 is $90.32 \%$ with the attendance of the board of commissioners meetings at most $100 \%$, one of which is owned by ARTI (PT. Ratu Prabu Energy Tbk) in 2018, while the lowest was $44.4 \%$ owned by BSSR (PT.Baramulti Suksessarana Tbk) in 2018. The average age of mining companies listed on the IDX in 2016-2018 is 13 years old with the oldest company being 28 years old owned by BUMI (PT. Bumi Resources Tbk) in 2018, while the youngest is three years old (in 20161 year old) which is owned by MDKA (PT. Merdeka Copper Gold Tbk).

By using 22 integrated reporting indicators, the average In (IR) result of mining companies listed on the IDX in 2016-2018 is 0.832 , which is $83.2 \%$, which means that the use of IR elements in the annual reports of mining sector companies is relatively high with a standard deviation of 0.091 , it shows lower results than the average, reflecting that the IR spread is relatively low. The highest reaches $95 \%$, one of which is owned by ADRO (PT. Adaro Energy) in 2018, according to researchers the reason ADRO has a high IR spread because ADRO is the largest supplier of domestic coal that prioritises environmental friendliness in order to preserve the environment and gets a good image as one of the ways to get investors. In contrast, the lowest value is owned by PKPK (PT. Perdana Karya Perkasa Tbk) in 2016 with In (IR) of 45\%. PKPK (PT. Perdana Karya Perkasa Tbk) has the lowest IR spread because its business activities do not focus on coal exploitation, this company is also engaged in gas petroleum construction mining and heavy equipment rental. With this low-value PKPK (PT. Perdana Karya Perkasa Tbk) may ignore the impact of its operations on the environment because it is also engaged in the service sector.

\section{Board Size and Integrated Reporting Implementation}

The regression test results for the Board size variable have a count of 3.524 and a significance value of 0.001 . Because the significance value obtained is $\operatorname{Sig} 0,000<0.05$, it can be concluded that the Board of Commissioners influences the Implementation of Integrated Reporting. The higher the number of the Board of Commissioners will impact the implementation of Integrated Reporting. The primary role played by the board of commissioners is to guarantee the company's strategy to maximise firm value.

The board of commissioners also acts as a representative of shareholders; with this role, the commissioners' board wants to maintain shareholder trust. The board of commissioners is tasked with providing advice and input to the board of directors regarding policies that follow the principles of GCG, one of which is by providing advice on policies to implement the elements of Integrated Reporting. 
Table 3. Statistic t-Test

\begin{tabular}{|c|c|c|c|c|c|}
\hline & \multicolumn{2}{|c|}{$\begin{array}{l}\text { Unstandardised } \\
\text { Coefficients }\end{array}$} & \multirow{2}{*}{$\begin{array}{c}\text { Standardised } \\
\text { Coefficients }\end{array}$} & \multirow[t]{2}{*}{$\mathrm{t}$} & \multirow[t]{2}{*}{ Sig. } \\
\hline & B & Std. Error & & & \\
\hline & 0,281 & 0,138 & & 2,031 & 0,044 \\
\hline BOCSize (X1.1) & 0,016 & 0,005 & 0,297 & 3,496 & 0,001 \\
\hline BOCInd (X1.2) & 0,181 & 0,075 & 0,203 & 2,419 & 0,017 \\
\hline AUDTC (X1.3) & 0,03 & 0,016 & 0,144 & 1,856 & 0,066 \\
\hline MetATC (X1.4) & 0,001 & 0,001 & 0,082 & 1,055 & 0,293 \\
\hline Umur (X2) & 0,003 & 0,001 & 0,226 & 2,921 & 0,004 \\
\hline Size (X3) & 0,008 & 0,004 & 0,153 & 1,704 & 0,091 \\
\hline
\end{tabular}

Table 4. Statistic F-Test

\begin{tabular}{|c|c|c|c|c|c|}
\hline & $\begin{array}{l}\text { Sum of } \\
\text { Squares }\end{array}$ & df & Mean Square & $\mathrm{F}$ & Sig. \\
\hline Regression & 0,352 & 6 & 0,059 & 9,828 &, $000 \mathrm{~b}$ \\
\hline Residual & 0,747 & 125 & 0,006 & & \\
\hline Total & 1,099 & 131 & & & \\
\hline \multicolumn{6}{|c|}{ a. Dependent Variable: IR (Y) } \\
\hline
\end{tabular}

Independent Board of Commissioners and Integrated Reporting Implementation

The regression test results for the Board of Commissioners Independent variables have a count of 2.419 and a significance value of 0.017 . Because of the significant value obtained by Sig. $0.017<0.05$, it can be concluded that the Independent Board of Commissioners influences the Implementation of Integrated Reporting. The higher the number of Independent Commissioners, the impact on the implementation of Integrated Reporting. The quantity of the independent board of commissioners in a company will benefit the company because it will improve its supervisory function to minimise information asymmetry described in agency theory. So it can be concluded that the more the number of independent commissioners to the total members of the company commissioners, the transparency as one of the principles of GCG is implemented effectively. In line with research conducted by Hermalin and Weisbach.

Audit Committee and Integrated Reporting Implementation

The regression testing results on the Audit Committee variable have a count of 1.856 and a significance value of 0.066 . Because of the significant value obtained by Sig. 0.066>0.05, it can be concluded that the Audit Committee does not influence the Implementation of Integrated Reporting. The higher the number of Audit Committees will not affect the 
implementation of Integrated Reporting. The audit committee is considered not to affect the implementation of Integrated Reporting because the audit committee's task is to maintain the credibility of the company's financial reporting, which focuses more on reporting related to operational activities, investment and company funding so that disclosure of Integrated Reporting is not the focus of the audit committee.

\section{Board's Meeting Attendance and Integrated Reporting Implementation.}

The regression testing results on the Meeting Attendance variable have a value of 1.055 and a significance value of 0.293 . Because of the significant value obtained by Sig. 0.293>0.05, it can be concluded that Meeting Attendance does not influence the Implementation of Integrated Reporting. The higher the number of meeting attendances will not affect the implementation of Integrated Reporting. The board of commissioners' meeting is considered not to be effective in determining and changing management policies. Even though the frequency of meetings is frequent, this is not an excuse for the management to implement its policies and regulations. The board of commissioners' meeting has not been able to be responsible for the internal control in controlling corporate governance. Therefore, the board of commissioners meeting has not influenced Integrated Reporting implementation, the company's policy.

\section{Company's Age and Integrated Reporting Implementation}

The regression testing results on the firm age variable have $t$ value of 2.921 and a significance value of 0.004 . Because of the significant value obtained by Sig. $0.004<0.05$, it can be concluded that Company Age influences the Implementation of Integrated Reporting. The higher the age of the company, the impact on the implementation of Integrated Reporting. Companies with a longer operating life will be in line with the wider disclosure of financial statements such as integrated reports to get better the image given to the public. Companies operating for a more extended period have the awareness to present a broader report to meet stakeholder needs. The length of time a company affects integrated reporting is in line with agency theory, which states that the longer the company operates, the greater the information asymmetry (Jensen \& Meckling: 1976).

Corporate governance and Integrated Reporting Implementation

By testing the coefficient of partial determination, good corporate governance results are obtained, consisting of board size, independent board of commissioners, audit committee, meeting attendance, and company age and firm size as control variables simultaneously contributing an influence of $32.1 \%$ implementation Integrated Reporting. Company size is considered necessary in the mining sector because its activities are to extract and exploit natural resources. The bigger the company's size is considered, the broader its disclosure of information on company activities.

The structure of good corporate governance, the company's age, and its size have a role in monitoring company activities. Each element has a relationship and works together to solve problems that exist within a company. With these elements, the company can realise transparency and responsibility for disclosing information, including viewing integrated reports. This information includes a picture of the whole company needed by stakeholders to create value and reflect its condition in the short, medium and long term.

\section{Conclusion}

Based on the results of the analysis and discussion, the researchers obtained several conclusions. The board size has a significant effect on the implementation of integrated reporting with the contribution of the effect of $11.3 \%$ where the higher the board size will have an impact on the increase in the implementation of the integrated reporting value, on the other hand, a small board size can result in a lower implementation of integrated reporting.

Independent board of commissioners has a significant influence on the implementation of integrated reporting with a contribution of influence given of $6.3 \%$ where the higher the independent board of commissioners will have an impact on the 
higher implementation of integrated reporting, on the other hand, a low independent board of commissioners can result in the lower implementation of integrated reporting. The audit committee does not significantly influence the implementation of integrated reporting, where the more the number of audit committees will not necessarily impact changes in the implementation of integrated reporting. Meeting attendance does not significantly affect the implementation of integrated reporting, where higher meeting attendance does not necessarily impact changes in the implementation of integrated reporting.

The age of the company has a significant influence on the implementation of integrated reporting with the contribution of the effect of $6.2 \%$ where the older the age of the company will have an impact on the higher implementation of integrated reporting. Firm size has a significant influence on the implementation of integrated reporting with the contribution of the effect of $4.8 \%$ where the larger the size of the company will have an impact on the higher the implementation of integrated reporting. Good corporate governance structure, company age, and company size together influence the implementation of integrated reporting with a contribution of $32.1 \%$.

\section{Suggestion}

Further researchers should use a sample of more than one sector and use several years of observation so that it will be able to determine whether there is an effect each year also add independent variables such as institutional ownership, managerial ownership, foreign ownership, and family ownership. We recommend that in future research related to measurement not only using the content element but also using the guiding principles and makes comparisons with countries that have implemented integrated reporting as mandator.

Companies can apply the principles of GCG in the company's operations, not just a formality for reporting. Moreover, it explains corporate governance changes from year to year that there is a change in better governance every year. Although integrated reporting is voluntary, the company should begin requiring integrated reporting for broader reporting and also follow developments in reporting. The government is expected to standardise integrated reporting elements and make regulations that oblige companies to implement integrated reports.

\section{References}

ACCA, \& Eufosif. (2013, Juni 27). What do Investors Expect from Non-Finansial Reporting www.accaglobal.com

Adams, Carol A. 2013. Understanding Integrated Reporting Reporting. New York: Greenleaf Publishing Book.

Ahmad, Rudy (2017). Pengaruh Struktur Corporate Governance Terhadap Tingkat Keselarasan Laporan Tahunan Dengan Rerangka Integrated Reporting. https://doi.org/10.1016/j.sbspro.2015.04.758

Agyei-Boapeah, H., Ntim, C. G., \& Fosu, S. (2019). Governance Structures and the Compensation of Powerful Corporate Leaders in Financial Firms during M\&As. Journal of International Accounting, Auditing and Taxation, 37, 1-20. https://doi.org/10.1016/j.intaccaudtax.2019.10 0285

Charles, F. J. (2006). Corporate Governance. Corporate Reputation Review. 1.

Chariri \& Januarti. (2017). Eksplorasi Elemen Integrated Reporting Dalam. XXI(September), 411-424. https://doi.org/10.24912/ja.v21i3.245

Churet, C., et al. (2014). Integrated Reporting, Quality of Management, and Financial Performance. Journal of Applied Corporate Finance. 8.

Ernst and Young. (2014). Integrated Reporting Elevating Value. Diambil pada tanggal 19 Januari 2017. dari EY: www.ey.com

Ghozali. (2007). “Teori Akuntansi”. Semarang: Badan Penerbit Universitas Diponegoro

Ghozali, I. 2011. Aplikasi Analisis Multivariate Bottom Line. dengan Program IBM SPSS 19. Semarang: Undip. 
Ghozali, Imam. 2013. Aplikasi Analisis Multivariat dengan Program IBM SPSS. Edisi 7. Semarang: Penerbit Universitas Diponegoro.

Hartini, Sri. 2012. "Hubungan Orientasi Pasar, Strategi Bersaing, Kewirausahaan Korporasi Dan Kinerja Perusahaan.” Jurnal Ekonomi Dan Keuangan $17 \quad$ (80): $39-53$. doi:http://dx.doi.org/10.24034/j25485024.y201 3.v17.i1.2220.

Hermalin, B. E., \& Weisbach, M. S. (1998). The Detrerminants of Board Composition. Rand Journal of Economics, 19(4). 589-606.

Hery. (2012). Akuntansi dan Rahasia Dibaliknya (untuk para manajemen nonakuntansi). (Edisi Satu). Jakarta: PT. Bumi Aksara.

International Integrated Reporting Councils. (2013). The International Framework. UK: IIRC.

Jensen, M. C., \& Meckling, W. H. (1976). Theory of The Firm: Managerial Behaviour,

Agency Costs and Ownership Structure. Journal of Financial Economics. 4. 60- 305.

Kalangit, Holy K. M. (2009). Konsep Corporate Social Responsibility, Pengaturan dan pelaksanaan di Indonesia. Bogor: Lingkar Studi CSR/A + CSR Indonesia.

Kaya, D. (2014). The Influence of FirmSpecific Characteristics on the Extent of Voluntary Disclosure in XBRL. Journal of Accounting and Information Management, 22(1), 2--17.

Khairina, D. (2018). Pengaruh Integrated Reporting Terhadap Asimetri Informasi. Skripsi, 151, 1-85. https://doi.org/10.1145/3132847.3132886

Kılıç, M., \& Kuzey, C. (2018). Determinants of forward-looking disclosures in integrated reporting. Managerial Auditing Journal, 33(1), $115-144$.

KNKG. (2006). Pedoman Umum Good Corporate Governance Indonesia. Jakarta: Komite Nasional Kebijakan Governance.

Nazier, D. M., \& Umiyati, I. (2014). Transformasi sustainability Reporting Menuju
Integrated Reporting (IR) sebagai Cerminan Semakin Luasnya Akuntabilitas dalam Corporate Governance. STIE Sutaatmadja Subang. 4.

Nugroho, Rico, Bambang Swasto Sunuharjo, and Ika Ruhana. 2017. "Kinerja Karyawan Studi Pada Karyawan Badan Pusat Statistik (BPS) Kabupaten Kediri)." Jurnal Administrasi Bisnis $\quad 45$ (1): 19-26. http://administrasibisnis.studentjournal.ub.ac.i d/index.php/jab/article/view/1747.

Nurhidayat, I. (2011). Analisis Pengaruh Penerapan Good Corporate Governance

(GCG) terhadap Nilai Pasar Perusahaan Perbankan Publik di Indonesia Tahun 20032007. Tesis. UGM

Nurrahman, A., \& Sudarno. (2013). Pengaruh Kepemilikan Manajerial, Kepemilikan

Institusional, dan Kepemilikan Asing terhadap Praktik Pengungkapan

Sustainability Report. Diponegoro Journal of Accounting. 2(1). 1-14.

Organisation for Economic Cooperation and Development (OECD). (2004). OECD

Principles of Corporate Governance. Diambil pada tangga 4 Febuari 2017. Dari www.oecd.org

Otoritas Jasa Keuangan. (2018). Statistik Perbankan Syariah. (Online). (https://www.ojk.go.id/)

Puspita, G. M. (2014). Pengaruh Penerapan Good Corporate Governance (GCG) terhadap Rasio Return On Assets (ROA), Return On Equity (ROE), dan Economic Value Added (EVA). Skripsi. UGM

Prijanto, T., \& Widianingsih, Y. (2012). FaktorFaktor yang Mempengaruhi Voluntary Disclosure Perusahaan Go Public. Jurnal Akuntansi Dan Sistem Teknologi Informasi, 9(1), 23-31.

Roth, P. H. (2014). Is Integrated Reporting in the Future? Considering the Costs,

Benefits, and Role of CPAs Management Corporate Finance. The CPA Journal 
Sari, A. R., dkk. (2013, September). Pengaruh Kepemilikan Institusional, Komposisi

Dewan Komisaris, Kinerja Perusahaan terhadap Luas Pengungkapan Corporate

Social Responsibility di dalam Sustainability Report pada Perusahaan Manufaktur yang terdaftar di BEI. Jurnal Aplikasi Manajemen. 11(3). 481-491

Sapitri, S. D. (2016). Pengaruh Umur Perusahaan, Ukuran Perusahaan Dan Operating Leverage Terhadap Struktur Modal. Https://Doi.Org/10.5151/Cidi2017-060

Sawitri, A. P. (2016). Anteseden Luas Lingkup Pengungkapan Sukarela dan Pengaruhnya Terhadap Asimetri Informasi. Majalah Ekonomi, Vol 21(1), Page 1-15.

Sarwono, J. (2006). Metode Penelitian Kuantitatif dan Kualitatif. Yogyakarta: Graha Ilmu.

Umar, H. (2011). Metode Penelitian untuk Skripsi dan Tesis Bisnis. Jakarta: PT Raja Grafindo Persada.

Wardani, R. P. (2012). Faktor-Faktor yang Mempengaruhi Luas Pengungkapan Sukarela. Jurnal Akuntansi Dan Keuangan, 14, 1-15.

Waryanto. (2010). Pengaruh Karakteristik Good Corporate Governance (GCG) Terhadap
Setyarini, R. (2018). SKRIPSI Oleh : Yakarta. Analisis Pengaruh Ukuran Perusahaan, Umur Perusahaan, Profitabilitas, Leverage, Dan Pertumbuhan Perusahaan Terhadap Corporate Social Responsibility (Studi, 1-179).

Susanti, S., \& Riharjo, I. B. (2013). Pengaruh Good Corporate Governance terhadap

Corporate Social Responsibility pada Perusahaan Cosmetics and Household. Jurnal Ilmu dan Riset Akuntansi. 152-167.

Stiglitz, J. (2009). The Financial Crisis of 2007/2008 and its Macro-conomic Consequences. New York. NY: Columbia University.

Solihin, Ismail. 2009. Corporate social responsibility from charity to sustainability. Salemba Empat. Jakarta.

Tarjo. (2002). Analisa Free Cash Flow dan Kepemilikan Manajerial terhadap Kebijakan Utang Pada Perusahaan publik di Indonesia. Tesis. UG

Luas Pengungkapan Corporate Social Responsbility (CSR) Di Indonesia. Skripsi, 1145.

Wulandari, N., \& Budiartha, I. (2014). Pengaruh Struktur Kepemilikan, Komite Audit, Komisaris Independen Dan Dewan Direksi Terhadap Integritas Laporan Keuangan. EJurnal Akuntansi, 7(3), 574-586. 